JURNAL ILMIAH MANAJEMEN BISNIS DAN INOVASI UNIVERSITAS SAM RATULANGI (JMBI UNSRAT)

\title{
REAKSI PASAR MODAL TERHADAP PERISTIWA VIRUS CORONA (COVID-19) PADA PERUSAHAAN MAKANAN DAN MINUMAN YANG TERDAFTAR DI BURSA EFEK INDONESIA
}

\author{
Inri B. Sambuari, Ivonne S. Saerang, Joubert B. Maramis
}

Universitas Sam Ratulangi

A R T I C L E IN F O

Keywords: Event Study, Abnormal Return, Trading

Frequency, Market

Capitalization

Kata Kunci: Event Study, Abnormal Return, Frekuensi Perdagangan, Kapitalisasi Pasar
Abstract: The capital market is not only a funding facility for the companies but also means for investment activities. So many roles of the capital market in economic activities will have an impact on the sensitivity of the market reaction to events that occur. At the end of 2019, a new virus emerged in China, called the Corona Virus Disease 2019 or COVID-19. In Indonesia, the first case of COVID-19 was approved directly by President Joko Widodo on March 2020. The purpose of this research is to discover informations regarding the first reporting of COVID-19 in Indonesia, as well as abnormal return, frequency of trade, and market capitalization before and after the event. The observation began 30 days before the event and 30 days after the event. This study uses quantitative research in the comparative method. The sample uses judgment sampling with total of 22 food and beverage companies listed on the Indonesia Stock Exchange. The finding show did not contain information that caused the market to be disapproved. This is proven by the absence of significant results in daily tests on the indicators. The results were also not significant in the combined abnormal return test and the combined market capitalization test. The trade comparison test results show a significant difference which means there was a market-panic towards trading activities after the event that caused some frequency differences, before and after the event in terms of trade transactions.

Abstrak: Pasar modal sebagai sarana pendanaan bagi perusahaan dan sarana bagi kegiatan berinvestasi. Semakin besar peran pasar modal dalam kegiatan ekonomi, maka semakin sensitif pula reaksi pasar terhadap peristiwa disekitarnya. Akhir tahun 2019 muncul sebuah virus baru di Cina, yang disebut Virus Corona (COVID-19). Kasus pertama Virus Corona (COVID-19) di Indonesia diumumkan oleh Presiden Joko Widodo pada 2 Maret 2020. Penelitian ini dilakukan untuk mengetahui kandungan informasi atas peristiwa pengumuman kasus pertama Virus Corona (COVID-19) di Indonesia, serta perbedaan abnormal return, frekuensi perdagangan, dan market capitalization sebelum dan setelah peristiwa. Periode pengamatan dilakukan selama 30 hari sebelum dan 30 hari setelah peristiwa. Jenis penelitian kuantitatif dengan menggunakan metode komparatif. Sampel yang digunakan yaitu judgement sampling, dengan jumlah 22 perusahaan makanan dan minuman yang terdaftar di Bursa Efek Indonesia. Hasil penelitian menunjukan peristiwa ini tidak mengandung informasi yang menyebabkan pasar tidak bereaksi. Hal ini dibuktikan dengan tidak terdapatnya hasil signifikan dalam uji harian pada tiga indikator. Dan pada hasil uji gabungan abnormal return dan uji gabungan market capitalization diperoleh hasil yang tidak signifikan. Namun hasil uji gabungan frekuensi perdagangan menunjukan adanya perbedaan signifikan, yang artinya terjadi kepanikan pasar terhadap aktivitas perdagangan setelah peristiwa, sehingga adanya perbedaan frekuensi sebelum dan setelah peristiwa dari segi transaksi perdagangan. 


\section{Pendahuluan}

\section{Latar Belakang Penelitian}

Pasar modal memiliki peran penting bagi perekonomian suatu negara karena pasar modal menjalankan dua fungsi, yaitu sebagai sarana bagi pendanaan usaha dan sarana bagi masyarakat untuk berinvestasi pada instrumen keuangan. Pasar modal Indonesia telah memperlihatkan perkembangannya dengan jumlah perusahaan IPO 2019 tertinggi di Asean. Semakin besar peran pasar modal dalam kegiatan ekonomi, maka semakin sensitif pula reaksi pasar terhadap peristiwa disekitarnya. Hal ini dikarenakan kondisi ekonomi suatu negara akan memengaruhi kestabilan harga saham dan transaksi perdagangan di pasar modal. Oleh sebab itu, kegiatan perdagangan saham di pasar modal yang merupakan bagian dari aktivitas ekonomi, tak lepas dari pengaruh suatu peristiwa.

Akhir tahun 2019, dunia dihebohkan oleh munculnya sebuah virus baru yang disebut Virus 2019 Novel Coronavirus (2019-nCoV) yang lebih dikenal dengan nama Virus Corona yang muncul pertama kali di Kota Wuhan, Cina. Coronavirus adalah kumpulan virus yang bisa menginfeksi sistem pernapasan dan dapat menular dari manusia ke manusia. Virus Corona dilaporkan terjadi di lebih dari setengah negara di dunia. Lebih dari 113.000 orang telah terinfeksi Virus Corona, dan lebih dari 4.000 orang meninggal dunia karena penyakit COVID-19. Di Indonesia kasus Virus Corona pertama terjadi pada awal bulan Maret. Yang disampaikan oleh Presiden Indonesia Joko Widodo dalam pidatonya di Istana Kepresidenan, Jakarta pada 2 Maret 2020. Jokowi mengatakan, dua orang yang positif Virus Corona terinfeksi dari warga negara Jepang yang datang di Indonesia. Media Internasional juga ikut merilis berita mengenai konfirmasi tersebut. Kemenkes menetapkan kasus Virus Corona sebagai Kejadian Luar Biasa (KLB) pada 3 Maret 2020.

Munculnya Virus Corona membuat seluruh aspek di negeri "Tirai Bambu" lumpuh total. Perekonomian negera tersebut juga ikut terganggu, dan berdampak pada negara-negara lain di Kawasan Asia Tenggara, bahkan secara global. Akibat dari virus ini, banyak investor asing melepas saham-sahamnya akibat kepanikan pasar modal di luar negeri mengalami penurunan drastis. Bursa Asia ikut bereaksi atas peristiwa ini. Tak hanya di Kawasan Asia, di Amerika Serikat dan Eropa juga mengalami penurunan. Asian Development Bank $(A D B)$ memperkirakan wabah Virus Corona menyebabkan kerugian ekonomi global sebesar US\$347 miliar atau setara dengan Rp. 4.944 triliun. Virus Corona dipastikan berdampak pada sektor ekonomi Indonesia, di mana aliran modal keluar atau capital outflow di pasar saham juga terjadi sebanyak Rp. 980 miliar.

Peristiwa yang hendak diuji kandungan informasinya terhadap pasar modal adalah peristiwa Virus Corona di Indonesia. Pengujian kandungan informasi terhadap aktivitas pasar ini dimaksud untuk melihat reaksi pasar terhadap peristiwa tersebut. Apabila mengandung informasi kuat, maka akan ada reaksi yang diterima oleh pasar. Reaksi peristiwa Virus Corona ini diukur menggunakan abnormal return sebagai nilai perubahan harga, dan untuk memastikan apakah ada pengaruh informasi terhadap peristiwa Virus Corona yang terjadi di Indonesia. Dengan terjadinya abnormal return dapat dikatakan bahwa suatu pengumuman peristiwa yang mempunyai kandungan informasi akan memberikan abnormal return kepada pasar. Aktivitas frekuensi perdagangan saham merupakan salah satu bahan untuk melihat reaksi terhadap sebuah informasi yang masuk pada pasar modal (Silviyani dkk, 2014) dalam Taslim dan Wijayanto (2016). Terjadinya peningkatan permintaan saham akan meningkatkan frekuensi perdagangan. Meningkatnya jumlah frekuensi transaksi perdagangan maka harga saham akan terdorong naik sehingga return saham juga akan meningkat. Kandungan informasi juga mampu memengaruhi nilai perdagangan saham. Menurut Sudiatno dan Suharmanto (2011) dalam Taslim dan Wijayanto (2016) semakin besar kapitalisasi pasar suatu saham, semakin lama pula investor menahan kepemilikan sahamnya, karena investor menganggap bahwa perusahaan besar akan cenderung lebih stabil dari sisi keuangannya. Untuk melihat suatu peristiwa 
mengandung abnormalitas atau tidak, digunakan penelitian metode study event. Event study merupakan penelitian dengan mempelajari reaksi pasar terhadap suatu peristiwa yang informasinya dipublikasikan sebagai suatu pengumuman dengan mengambil sampel berupa penutupan harga saham.

Dipilihnya subsektor makanan dan minuman karena makanan dan minuman adalah kebutuhan dasar yang dibutuhkan manusia untuk bertahan hidup, maka saham dari perusahaan tetap mampu mencetak keuntungan meskipun kondisi ekonomi sedang memburuk. Untuk itu dapat dilihat apakah subsektor makanan dan minuman mampu bertahan dalam kondisi negara tidak stabil akibat peristiwa Virus Corona ini.

\section{Tujuan Penelitian}

Untuk menganalisis dan mengukur adanya reaksi pasar modal, dengan terdapatnya perbedaan antara:

1. Abnormal return

2. Frekuensi perdagangan

3. Market capitalization

Pada periode sebelum dan setelah pengumuman kasus pertama Virus Corona (COVID-19) di Indonesia pada perusahaan makanan dan minuman yang terdaftar di Bursa Efek Indonesia.

\section{Pasar Modal}

\section{Tinjauan Pustaka}

Definisi pasar modal menurut kamus pasar uang dan modal adalah pasar konkret atau abstrak yang mempertemukan pihak yang menawarkan dan memerlukan dana jangka panjang, yaitu jangka satu tahun ke atas. Pasar modal memberikan jasanya yaitu menjembatani hubungan antar pemilik modal yang disebut pemodal (investor) dengan peminjam dana yang disebut emiten (perusahaan yang go public).

\section{Teori Efisiensi Pasar}

Konsep efisiensi pasar membahas tentang hubungan antara harga atau nilai sekuritas dengan informasi, bagaimana pasar bereaksi terhadap informasi-informasi, dan sejauh mana informasi dapat memengaruhi pergerakan harga saham yang terbentuk (Hanafi, 2004) dalam Akbar (2019). Kondisi pasar dikatakan efisien, apabila pasar bereaksi dengan cepat dan akurat untuk mencapai harga keseimbangan baru terhadap informasi yang tersedia.

\section{Teori Pensinyalan}

Teori pensinyalan menjelaskan mengapa informasi yang dipublikasikan oleh perusahaan sebagai suatu pengumuman akan memberikan sinyal bagi para investor dalam pengambilan keputusan investasi (Jogiyanto, 2000:392) dalam Sihotang (2015). Suatu respon atas sinyal positif menunjukkan bahwa suatu pengumuman atau informasi, menghasilkan pergeseran yang positif atas kekayaan pemegang saham dengan adanya kenaikan harga saham.

\section{Abnormal Return}

Abnormal return adalah hasil yang tidak sesuai harapan atau selisih antara actual return dengan expect return. Actual return adalah keuntungan yang diperoleh dari hasil investasi. Sedangkan expect return adalah keuntungan yang diharapkan investor dikemudian hari terhadap dana yang telah ditempatkannya. 


\section{Frekuensi Perdagangan}

Frekuensi perdagangan saham adalah jumlah transaksi perdagangan saham pada periode tertentu (Silviyani, 2014) dalam Taslim dan Wijayanto (2016). Frekuensi menggambarkan berapa kali saham suatu emiten diperjualbelikan dalam kurun waktu tertentu.

\section{Market Capitalization}

Market capitalization atau kapitalisasi pasar merupakan nilai pasar dari saham yang diterbitkan suatu emiten. Kapitalisasi pasar yang besar umumnya menjadi salah satu daya tarik para investor dalam memilih saham.

\section{Penelitian Terdahulu}

Ida Nuryana (2015) dalam penelitian Peristiwa Pengangkatan Joko Widodo sebagai Presiden tidak memiliki kandungan informasi, dibuktikan dengan tidak signifikannya nilai abnormal return dan trading volume activity selama periode pengamatan. Dan hasil uji beda rata-rata sebelum dan sesudah peristiwa yang tidak signifikan.

Akbar, Saerang, dan Maramis (2019) dalam penelitian Reaksi Pasar Modal Terhadap Pengumuman Kemenangan Presiden Joko Widodo Berdasarkan Keputusan KPU Pemilu Periode 2019-2024 dengan terdapat perbedaan abnormal return dan trading volume activity artinya pasar bereaksi. Sedangkan, ATVA menunjukkan tidak terdapat perbedaan secara parsial, namun terdapat perbedaan signifikan dalam uji ATVA gabungan.

Ramandani, Abrianto, dan Riawan (2019) dalam penelitian Pengaruh Peristiwa Jatuhnya Pesawat Lion Air Terhadap Abnormal Return dan Trading Volume menemukan bahwa pasar tidak bereaksi dengan tidak terdapat perbedaan abnormal return dan trading volume activity sebelum dan sesudah peristiwa.

\section{Hipotesis Penelitian}

Diduga terdapat perbedaan abnormal return, frekuensi perdagangan, dan market capitalization saham sebelum dan setelah pengumuman kasus pertama Virus Corona (COVID-19) di Indonesia pada perusahaan makanan dan minuman yang terdaftar di Bursa Efek Indonesia.

\section{Model Penelitian}

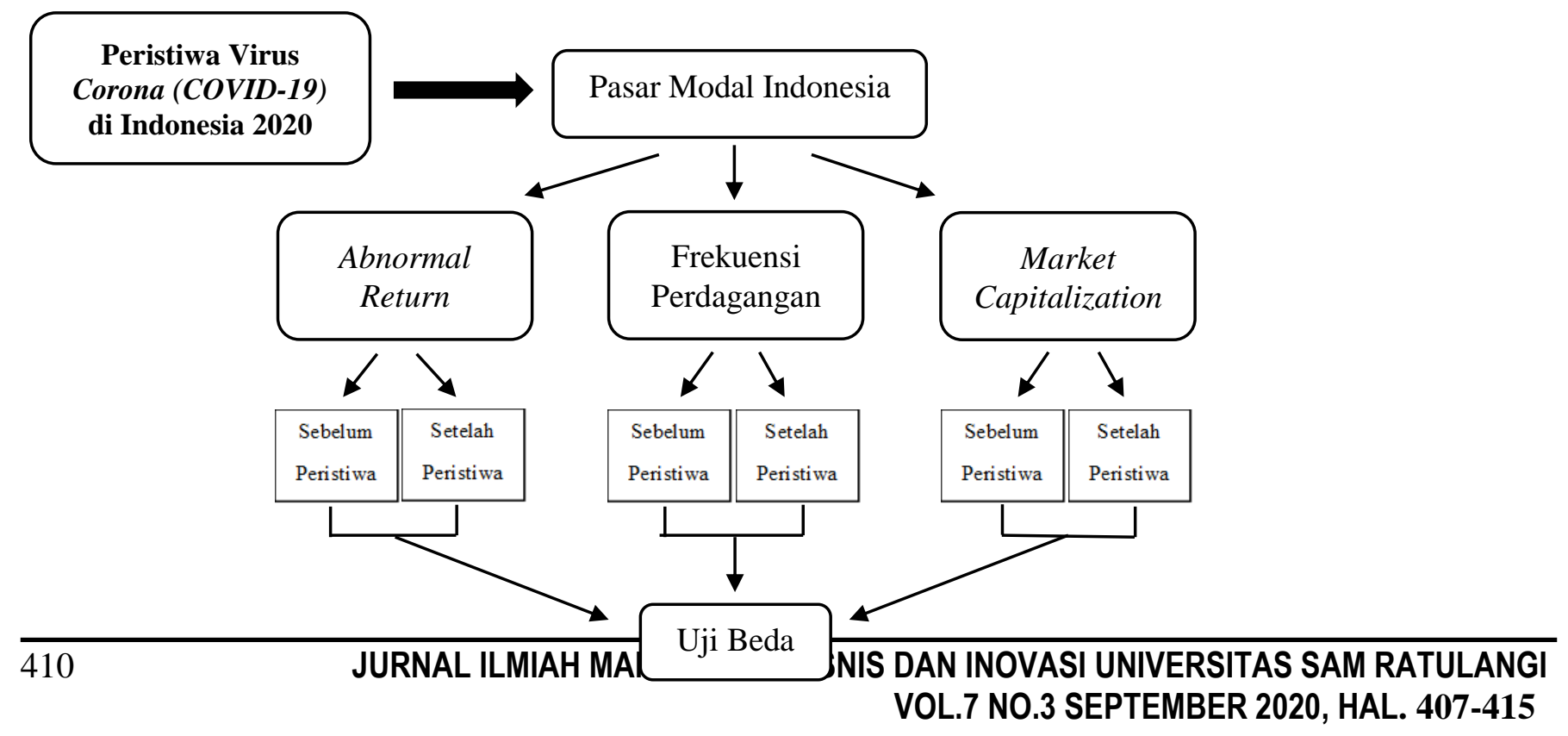




\section{Periode Jendela}

Periode jendela menggunakan periode pengamatan selama 30 hari sebelum peristiwa dan 30 hari setelah peristiwa. Karena menggunakan mean adjusted model, maka periode estimasi yang digunakan yaitu 10 hari sebelum periode pengamatan.

\section{Jenis Penelitian}

\section{Metode Penelitian}

Jenis penelitian berupa jenis komparatif, dengan metode kuantitatif menggunakan data pergerakan harga saham setiap hari kerja pada setiap perusahaan.

\section{Populasi, Sampel, dan Teknik Sampilng}

Populasi yang digunakan adalah saham di perusahaan sektor barang konsumsi, subsektor makanan dan minuman yang terdaftar di Bursa Efek Indonesia. Teknik pengumpulan sampel menggunakan judgement sampling, dengan kriteria: perusahaan yang sudah lama go public terhitung sebelum tanggal 6 Januari 2020, dan perusahaan yang tidak suspend. Maka jumlah sampel yang diperoleh sebanyak 22 sampel yang memenuhi kriteria.

\section{Data dan Sumber Data}

Jenis data yang digunakan adalah data rasio yang mempunyai nilai nol mutlak. Sumber data yang digunakan berupa data sekunder, yang diperoleh melalui web $\underline{w w w . i d x . c o . i d}$ untuk mengumpulkan harga saham harian (clossing price), jumlah transaksi perdagangan saham harian (frekuensi), dan nilai perdagangan saham (market capitalization).

\section{Teknik Pengumpulan Data}

Mengumpulkan dan mempelajari buku, literatur, jurnal, serta teori-teori yang berhubungan dengan penelitian ini. Dokumentasi digunakan untuk memperoleh data perdagangan saham harian.

\section{Definisi Operasional Variabel}

\section{Abnormal Return}

$$
\text { Abnormal Return }=\left[\sum \mathrm{Ri} / \mathrm{N}\right]-[(\mathrm{P} 1-\mathrm{P} 0) / \mathrm{P} 0]
$$

Keterangan:

$\mathrm{Ri}=$ Actual Return

$\mathrm{N}=$ Jumlah periode pengamatan

P1 = Harga saham hari ini

P0 = Harga saham kemarin

2. Frekuensi Perdagangan

$$
\sum \text { frekuensi }=\frac{\text { Jumlah frekuensi saham }}{\text { Hari pengamatan }}
$$

\section{Market Capitalization}

Keterangan:

$$
\mathrm{Vs}=\mathrm{Ps} \mathrm{x} \mathrm{Ss}
$$

$\mathrm{Vs}=$ Kapitalisasi pasar

Ps = Harga pasar 


\section{Ss = Jumlah saham yang diterbitkan}

\section{Teknik Analisis Data}

Uji normalitas digunakan untuk mengetahui apakah suatu data terdistribusi normal atau tidak, yang dilakukan dengan Uji Statistik Non-Parametik Kolmogorov-Smirnov (K-S). Uji-t berpasangan adalah pengujian hipotesis dimana data yang digunakan tidak bebas atau berpasangan yaitu individu (objek penelitian) dikenai dua perlakuan yang berbeda, menggunakan Uji Statistik Paired Sample Test.

\section{Hasil Penelitian}

\section{Uji Normalitas}

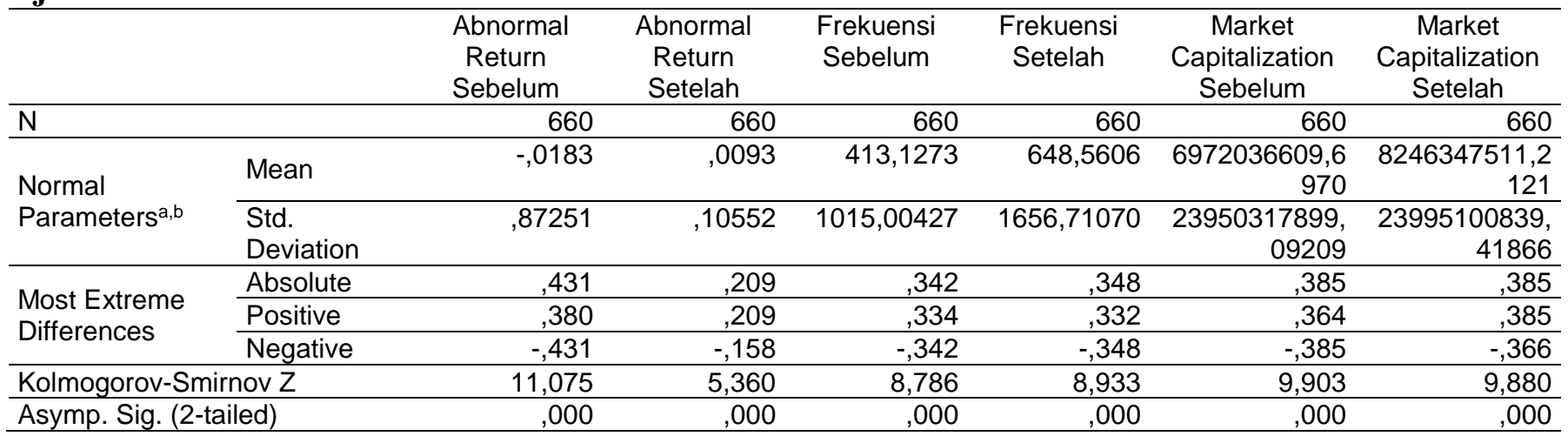

Nilai Asymp. Sig (2-tailed) dari abnormal return, frekuensi perdagangan, dan market capitalization sebelum dan sesudah peristiwa diperoleh nilai 0,000. Yang jika dibandingkan dengan probabilitas 0,05 maka hasilnya lebih kecil, sehingga dapat diketahui bahwa data penelitian tidak berdistribusi normal.

\section{Uji Gabungan Paired Sample Test}

\begin{tabular}{|c|c|c|c|c|c|c|c|c|c|}
\hline & \multicolumn{5}{|c|}{ Paired Differences } & \multirow[t]{3}{*}{$t$} & \multirow[t]{3}{*}{$\mathrm{df}$} & \multirow{3}{*}{$\begin{array}{l}\text { Sig. }(2- \\
\text { tailed) }\end{array}$} \\
\hline & & \multirow[t]{2}{*}{ Mean } & \multirow[t]{2}{*}{$\begin{array}{c}\text { Std. } \\
\text { Deviation }\end{array}$} & \multirow[t]{2}{*}{$\begin{array}{l}\text { Std. Error } \\
\text { Mean }\end{array}$} & \multicolumn{2}{|c|}{$\begin{array}{l}95 \% \text { Confidence Interval of } \\
\text { the Difference }\end{array}$} & & & \\
\hline & & & & & Lower & Upper & & & \\
\hline Pair 1 & $\begin{array}{l}\text { Abnormal Return } \\
\text { Sebelum - Abnormal } \\
\text { Return Setelah }\end{array}$ &,- 02768 & ,86468 & ,03366 &,- 09377 & ,03841 &,- 822 & 659 & ,411 \\
\hline Pair 2 & $\begin{array}{l}\text { Frekuensi Sebelum - } \\
\text { Frekuensi Setelah }\end{array}$ & $\begin{array}{r}- \\
235,4333 \\
3\end{array}$ & 1171,64937 & 45,60639 & $-324,98469$ & $-145,88198$ & $-5,162$ & 659 & ,000 \\
\hline Pair 3 & $\begin{array}{l}\text { Market Capitalization } \\
\text { Sebelum - Market } \\
\text { Capitalization } \\
\text { Setelah }\end{array}$ & $\begin{array}{r}- \\
1274310 \\
901,5151 \\
5\end{array}$ & $\begin{array}{r}2195316157 \\
2,85961\end{array}$ & $\begin{array}{r}8545256 \\
55,27393\end{array}$ & $\begin{array}{r}- \\
2952232096, \\
51034\end{array}$ & $\begin{array}{r}403610293,4 \\
8004\end{array}$ & $-1,491$ & 659 & ,136 \\
\hline
\end{tabular}

Hasil uji beda abnormal return gabungan adalah 0,411 > Sig (2-tailed). Hasil uji beda frekuensi perdagangan gabungan adalah $0,000<$ Sig $(2$-tailed). Hasil uji beda market capitalization gabungan adalah 0,136 > Sig (2-tailed). Hal ini menunjukkan bahwa hipotesis abnormal return dan market capitalization ditolak, artinya tidak terdapat perbedaan abnormal return dan market capitalization sebelum dan setelah 
peristiwa. Sedangkan hipotesis frekuensi perdagangan diterima, artinya terdapat perbedaan frekuensi perdagangan sebelum dan setelah peristiwa.

\section{Uji Harian Paired Sample Test}

Dari hasil periode pengamatan harian secara parsial (sebelum vs setelah) tidak terdapat hasil yang signifikan pada abnormal return, frekuensi perdagangan, dan market capitalization. Ini berarti secara keseluruhan pasar tidak bereaksi terhadap peristiwa pengumuman kasus pertama Virus Corona (COVID19) di Indonesia pada perusahaan makanan dan minuman yang terdaftar di Bursa Efek Indonesia.

\section{Pembahasan}

\section{Hipotesis I}

Tidak terdapat perbedaan abnormal return sebelum dan setelah peristiwa pengumuman kasus pertama Virus Corona (COVID-19) di Indonesia, baik dari hasil uji gabungan maupun hasil uji harian secara parsial (sebelum vs setelah), dapat diketahui bahwa peristiwa ini tidak memiliki kandungan informasi sehingga tidak ada reaksi yang timbul dan tidak mempunyai pengaruh besar bagi pelaku pasar terhadap kegiatan di pasar modal khususnya pada subsektor makanan dan minuman.

Hal ini terjadi akibat pengumuman yang disampaikan oleh Presiden Indonesia pada 2 Maret 2020 ini bersifat netral, di mana negara-negara lain di Asia Tenggara sudah duluan mengumumkan "first cases" Virus Corona sebelum peristiwa ini terjadi di Indonesia. Artinya informasi yang diperoleh investor cenderung sama, sehingga para investor tidak bisa lari untuk mengamankan investasi mereka dengan cara menginvestasikannya ke negara lain yang sudah duluan terkena wabah Virus Corona ini. Untuk itu kegiatan bursa cenderung diwarnai dengan aksi wait and see setelah pengumuman, dan investor tidak ingin terburuburu dalam pengambilan keputusan, sehingga peristiwa ini tidak memengaruhi imbal hasil tidak normal bagi investor.

\section{Hipotesis II}

Terdapat perbedaan frekuensi perdagangan sebelum dan setelah peristiwa pengumuman kasus pertama Virus Corona (COVID-19) di Indonesia dalam uji gabungan mengindikasikan informasi tersebut sebagai bad news bagi investor, disebabkan adanya sentimen yang menyebabkan kepanikan investor setelah makin bertambahnya jumlah korban positif Corona, sehingga investor melakukan panic selling. Akibatnya dana investor asing di pasar saham dalam negeri terus mengalami penarikan menuju investasi emas saat pasar saham sedang goyah. Hal ini dilihat dari kenaikan harga emas global diikuti oleh logam mulia Antam yang melonjak 12,14\%. Namun hasil uji harian secara pasrsial (sebelum vs setelah) menunjukkan hasil yang tidak signifikan. Artinya peristiwa ini berdampak ke aktivitas perdagangan saham tapi secara harian fluktuasinya kecil, sehingga hampir tidak terlihat adanya reaksi yang terjadi, walaupun sebenarnya reaksi itu ada.

Perbedaan frekuensi perdagangan saham tidak sebanding dengan perbedaan abnormal return. Setelah terjadinya kepanikan terus-menerus, OJK langsung mengeluarkan kebijakan buyback tanpa RUPS terlebih dahulu, untuk mengatasi penurunan IHSG dan mengurangi risiko terjadinya autoreject bawah. Akibatnya walaupun frekuensi perdagangan cukup tinggi setelah peristiwa, tidak membuat investor memperoleh abnormal return. Ini berarti meningkatnya jumlah frekuensi transaksi perdagangan, tidak selalu diikuti dengan peningkatan return saham. 


\section{Hipotesis III}

Tidak terdapat perbedaan market capitalization sebelum dan setelah peristiwa pengumuman kasus pertama Virus Corona (COVID-19) di Indonesia, baik dari hasil uji gabungan maupun hasil uji harian secara parsial (sebelum vs setelah), dapat dikatakan peristiwa ini kurang memiliki kandungan informasi kepada investor maupun trader sehingga tidak memengaruhi pengambilan keputusan investasi, dan dikarenakan investor masih melihat adanya peluang investasi pada saham-saham di perusahaan makanan dan minuman, dan perusahaan masih mampu memperoleh laba (walaupun tidak tinggi) karena mengingat makanan dan minuman adalah kebutuhan dasar sehari-hari yang tetap diperlukan walaupun adanya wabah Virus Corona.

\section{Penutup}

\section{Kesimpulan}

1. Peristiwa pengumuman kasus pertama Virus Corona (COVID-19) di Indonesia pada perusahaan makanan dan minuman yang terdaftar di Bursa Efek Indonesia, tidak memiliki kandungan informasi yang menyebabkan pasar modal bereaksi terhadap abnormal return dilihat dari segi tingkat pengembalian investasi.

2. Peristiwa pengumuman kasus pertama Virus Corona (COVID-19) di Indonesia pada perusahaan makanan dan minuman yang terdaftar di Bursa Efek Indonesia, memiliki kandungan informasi yang menyebabkan pasar modal bereaksi terhadap frekuensi perdagangan dilihat dari segi aktivitas transaksi perdagangan.

3. Peristiwa pengumuman kasus pertama Virus Corona (COVID-19) di Indonesia pada perusahaan makanan dan minuman yang terdaftar di Bursa Efek, tidak memiliki kandungan informasi yang menyebabkan pasar modal bereaksi terhadap market capitalization dilihat dari segi nilai pasar.

\section{Saran}

1. Bagi pihak manajemen, untuk berhati-hati dengan suatu peristiwa yang terjadi di Indonesia, karena apabila market capitalization stabil maka perusahaan tetap akan mampu mempertahankan harga saham. Sekalipun pasar terpengaruh akibat suatu peristiwa, hal itu tidak akan memberikan dampak secara langsung dengan penurunan nilai perusahaan secara drastis.

2. Bagi para investor, untuk tidak terburu-buru dalam pengambilan keputusan investasi dengan tidak mudah terpengaruh terhadap isu-isu negatif, melainkan menyeleksi dan mencermati dulu informasiinformasi yang diperoleh dari situs terpercaya, agar terhindar dari capital loss dan memperoleh capital gain dari suatu peristiwa di Indonesia.

3. Bagi penelitian dan pengembangan selanjutnya, diharapkan untuk menggunakan objek yang lebih banyak, tidak hanya terbatas pada subsektor saja. Selain itu bisa menggunakan model perhitungan abnormal return lainnya seperti market model atau market adjusted model, yang dikombinasikan dengan variabel lain sebagai perbandingan.

\section{Daftar Pustaka}

Akbar, E.P. (2019). Reaksi Pasar Modal Terhadap Pengumuman Kemenangan Presiden Joko Widodo Berdasarkan Keputusan KPU Pemilu Periode 2019-2024 (Studi pada Perusahaan BUMN yang Terdaftar di BEI). Skripsi. Manado: Universitas Sam Ratulangi. 
Bursa Efek Indonesia. (2019). Pencapaian BEI Tahun 2019. Status. 30 Desember 2019. https://mobile.twitter.com/IDX_BEI/status/1211560319627120641 Diakses 26 Januari_2020.

Djalante, R., Lassa, J., Setiamarga, D., Sudjatma, A., Indrawan, M., Haryanto, B., Mahfud, C., Sinapoy, M.S., Djalante, S., Rafliana, I., Gunawan, L.A., Surtiari, G.A., dan Warsilah, H. (2020). Review and analysis of current responses to COVID-19 in Indonesia: Period of January to March 2020. Progress in Disaster Science Journal. Vol. 6, April 2020. https://www.sciencedirect.com/science/article/pii/S2590061720300284 Diakses 24 April 2020.

Harga Saham (Clossing Price), Frekuensi Perdagangan Saham, dan Kapitalisasi Pasar https://idx.co.id Diakses Januari-April 2020.

Jamaludin, G., Mulyati S., dan Putri T.E. (2018). Comparative Analysis of Capital Market Reaction Before and After Announcement of Presidential Elections United States 2016 Donald Trump (Event Studies On Shares Member Index LQ45). Accruals Journal. Vol. 1, No. 1, March 2018. https://www.neliti.com/id/publications/277824/comparative-analysis-of-indonesia-capitalmarket-reaction-before-and-after-annou Diakses 5 Februari 2020.

Karamoy, H., dan Tasik, H.H.D. (2019). Peran Eksistensi Saham di LQ45 pada Kinerja Profitabilitas Perusahaan. Jurnal Ekuitas. Vol. 3, $\quad$ No. $1, \quad 2019$. https://ejournal.stiesia.ac.id/ekuitas/article/view/4117 Diakses 22 Juli 2020.

Kementerian Sekretariat Negara Republik Indonesia. (2020). Dua WNI Positif Terjangkit, Presiden Tegaskan Keseriusan Pemerintah Tangani Wabah Corona. Artikel. 2 Maret 2020. https://www.setneg.go.id/baca/index/dua_wni_positif_terjangkit_presiden_tegaskan_keseriusan_ pemerintah_tangani_wabah_corona Diakses 13 April 2020.

Nuryana, I. (2015). Analisis Reaksi Pasar Modal Terhadap Pengangkatan Joko Widodo sebagai Presiden Republik Indonesia. Jurnal Referensi. Vol. 4, No. 2.2015. https://jurnal.unitri.ac.id/index.php/refrensi/article/view/517 Diakses 23 Oktober 2019.

Pane, M.D. (2020). Virus Corona. Artikel. 10 Maret 2020. https://www.alodokter.com/virus-corona Diakses 11 Maret 2020.

Ramandani, E.K., Abrianto T.H., dan Riawan, (2019). Pengaruh Peristiwa Jatuhnya Pesawat Lion Air Terhadap Abnormal Return dan Trading Volume Activity. Jurnal ISOQUANT. Vol. 3, No. 2. http:/studentjournal.umpo.ac.id/index.php/isoquant/article/view/290 Diakses 12 Maret 2020.

Reeves, O.G. (2019). Uji Akurasi Support Resistance Berbasis Data Candlestick pada Industri Pertambangan yang Terdaftar di Indeks LQ45. Skripsi. Manado: Universitas Sam Ratulangi.

Sihotang, E.M., dan Mekel, P.A. (2015). Reaksi Pasar Modal Terhadap Pemilihan Umum Presiden Tanggal 9 Juli 2014 Di Indonesia (Studi di Perusahaan Konstruksi, Infrastruktur dan Utilitas pada BEI, Jakarta). Jurnal EMBA. Vol. 3, No. 1, Maret 2015. Hal. 951-960. https://ejournal.unsrat.ac.id/index.php/emba/article/view/15989/15500 Diakses 29 September 2019.

Taslim, A., dan Wijayanto, A. (2016). Pengaruh Frekuensi Perdagangan Saham, Kapitalisasi Pasar dan Jumlah Hari Perdagangan Terhadap Return Saham. Management Analysis Journal. Vol. 5, No.1, 2016. https://journal.unnes.ac.id/sju/index.php/maj/article/view/5781 Diakses 14 April 2020.

Wauran, P.C., dan Tumbuan W.A. (2017). Buku Ajar Bank dan Pasar Modal. Manado: Fakultas Ekonomi dan Bisnis, Universitas Sam Ratulangi. 